\title{
Phylogeny of Maricaulis Abraham et al. 1999 and proposal of Maricaulis virginensis sp. nov., M. parjimensis sp. nov., M. washingtonensis sp. nov. and $M$. salignorans sp. nov.
}

\author{
${ }^{1}$ GBF - German Research \\ Centre for Biotechnology, \\ Mascheroder Weg 1, \\ D-38124 Braunschweig, \\ Germany \\ 2 Gridysystems SA, \\ ParcBIT - Son Espanyol, \\ E-07120 Palma de Mallorca, \\ Spain \\ ${ }^{3}$ BCCM/LMG Bacteria \\ Collection, Universiteit \\ Gent, K. L. \\ Ledeganckstraat 35, \\ B-9000 Gent, Belgium \\ ${ }^{4}$ Dept of Microbiology and \\ Immunology, University of \\ British Columbia, \\ Vancouver, \\ British Columbia, Canada \\ ${ }^{5}$ Macaulay Research \\ Institute, Craigiebuckler, \\ Aberdeen AB15 8QH, UK
}

\author{
Wolf-Rainer Abraham, ${ }^{1}$ Carsten Strömpl, ${ }^{1}$ Antonio Bennasar, ${ }^{2}$ \\ Marc Vancanneyt, ${ }^{3}$ C. Snauwaert, ${ }^{3}$ J. Swings, ${ }^{3}$ John Smit ${ }^{4}$ \\ and Edward R. B. Moore \\ Author for correspondence: Wolf-Rainer Abraham. Tel: +49 531 6181419. Fax: +495316181411.
e-mail: wab@gbf.de
}

Keywords: Maricaulis virginensis, Maricaulis parjimensis, Maricaulis washingtonensis,
Maricaulis salignorans, sulfolipid

Keywords: Maricaulis virginensis, Maricaulis parjimensis, Maricaulis washingtonensis,
Maricaulis salignorans, sulfolipid

\section{INTRODUCTION}

Caulobacteria are dimorphic, prosthecate bacteria in which reproduction results in the separation of two cells that are morphologically and behaviourally distinct from each other. One of these cells is sessile, being non-motile, and prosthecate, possessing at least one elongated, cylindrical appendage, a prostheca (Staley, 1968). The other cell is flagellated, bearing one polar flagellum, by which it is motile. The mode of reproduction of the dimorphic, prosthecate bacteria is unique as a regular feature of a prokaryotic repro-

Published online ahead of print on 7 June 2002 as DOI 10.1099/ ijs.0.02248-0.

Abbreviations: ARDRA, amplified rDNA restriction analysis; CID, collisioninduced dissociation; FAB, fast atom bombardment; FAME, fatty acid methyl ester; ITS, internally transcribed spacer; PYE, peptone/yeast extract; SQDG, sulfoquinovosyl diacyl glycerol; SSCP, single-stranded conformational polymorphism.

The GenBank accession numbers for the $16 \mathrm{~S}$ rDNA sequences of strains MCS 10, MCS 30, MCS 31 and VKM B-1513 ${ }^{\top}$ are respectively AJ301664-AJ301667. ductive cycle. It helps to disperse the population at each generation, thereby minimizing competition among siblings for resources. These developmental and reproductive characteristics allow these bacteria to exist in oligotrophic habitats (Poindexter, 1981a), importantly, tolerating prolonged nutrient scarcity.

Caulobacteria are ecologically important because they are ubiquitous in water and are presumed to be responsible for considerable mineralization of dissolved organic material in aquatic environments, with the oligotrophic caulobacters being especially important when nutrient concentrations and ambient temperatures are low (Staley et al., 1987). Studies have revealed that practically any type of sea water contains caulobacteria (Jannasch \& Jones, 1960; Anast \& Smit, 1988).

The first isolation of a Caulobacter sp. was reported by Löffler (1890), from fresh water. He noticed the unusual nutrient requirements of the strain and he could not assign the strain to a known taxon. In 1935, Henrici and Johnson described the genus Caulobacter, 
with Caulobacter vibrioides as the type species (Henrici \& Johnson, 1935). Three decades later, Poindexter (1964) described Caulobacter maris and Caulobacter halobacteroides, the first two caulobacteria from sea water. At that time, the taxonomy of the members of the genus was based almost exclusively on the characteristic morphology and mode of reproduction (Poindexter, 1981b).

Anast \& Smit (1988) were the first to determine differences between freshwater and marine caulobacteria on a large set of strains. Stahl et al. (1992) sequenced the 16S rRNA of several isolates belonging to Caulobacter, revealing, for the first time, that members of Caulobacter actually formed two distinct lineages, one comprising the freshwater and brackish water Caulobacter strains and the other comprising most of the marine Caulobacter strains.

As caulobacteria are ubiquitous in water samples and are believed to play an important role in carbon cycling in their habitats, we became interested in this group of bacteria and evaluated the diversity of freshwater and marine Caulobacter, using lipid analysis (Abraham et al., 1997), immunological profiling and 16S rRNA gene sequences and compared these results with physiological data (Abraham et al., 1999). We observed all freshwater caulobacteria to belong to the genera Caulobacter and Brevundimonas. However, the truly marine, halophilic caulobacteria belong to a separate genus, which we named Maricaulis, consisting of a single species, Maricaulis maris (Abraham et al., 1999). We report here the characterization of a number of marine isolates, obtained from different habitats from a wide range of locations, that belong to this genus and propose four novel species.

\section{METHODS}

Strains. The strains used in this study were obtained from the ATCC, the All-Russian Collection of Microorganisms (VKM), the DSMZ and the Dept of Microbiology and Immunology, University of British Columbia, Vancouver, British Columbia, Canada (VC and MCS strains). For the origin of the isolates, see Table 1.

All strains were grown in marine-Caulobacter medium SPYEM containing $30 \mathrm{~g}$ sea salts (Sigma) and $0.5 \mathrm{~g} \mathrm{NH}_{4} \mathrm{Cl}$ in 11 deionized water. After autoclaving and cooling, $20 \mathrm{ml}$ $50 \times$ PYE, $2 \mathrm{ml} 50 \%$ glucose (sterile) and $5 \mathrm{ml}$ riboflavin $\left(0.2 \mathrm{mg} \mathrm{ml}^{-1}\right)$, filter-sterilized, were added $(50 \times$ PYE is $100 \mathrm{~g}$ peptone and $50 \mathrm{~g}$ yeast extract in 11 deionized water, autoclaved). The strains were grown in 21 flasks, at $30^{\circ} \mathrm{C}$ and 100 r.p.m. and biomass was harvested in the late exponential phase after $72 \mathrm{~h}$ by centrifugation at $5860 \mathrm{~g}$ at room temperature.

Genomic DNA base composition analysis. Genomic DNA was isolated from cell pellets according to the protocol of Wilson (1987), followed by treatment with RNase A (Sigma) at $50{ }^{\circ} \mathrm{C}$ for $2 \mathrm{~h}$ and additional phenol/chloroform/isoamyl alcohol extraction. DNA was enzymically digested and mean $\mathrm{G}+\mathrm{C}$ contents were determined by HPLC (Tamaoka $\&$ Komagata, 1984). Calculations were carried out according to Mesbah et al. (1989), using non-methylated lambda phage DNA (Sigma) as a standard.
16S rDNA sequencing. Genomic DNA for PCR targeting the 16S rRNA genes (Mullis \& Faloona, 1987) was prepared from individual colonies picked from agar media, as described previously (Moore et al., 1997). Taq polymeraseinitiated cycle sequencing with standard primers was carried out as described previously (Abraham et al., 1999, 2001). The sequence data were aligned with reference $16 \mathrm{~S}$ rRNA and 16S rRNA gene sequences (Maidak et al., 2001; Stoesser et al., 2001), using the evolutionarily conserved primary sequence and secondary structure (Gutell et al., 1985; Neefs et al., 1991) as references, and analysed using the programs of the PHYLIP package (Felsenstein, 1989), as described previously (Abraham et al., 1999, 2001).

DNA-DNA hybridization. DNA was isolated according to the protocol of Marmur (1961). DNA-DNA hybridizations were performed using a modification of the microplate method described by Ezaki et al. (1989), using an HTS7000 Bio Assay Reader (Perkin Elmer) for the fluorescence measurements. Biotinylated DNA was hybridized with single-stranded unlabelled DNA, non-covalently bound to microplate wells. Hybridizations were performed at $48{ }^{\circ} \mathrm{C}$ in hybridization mixture $(2 \times \mathrm{SSC}, 5 \times$ Denhardt's solution, $2.5 \%$ dextran sulfate, $50 \%$ formamide, $100 \mu \mathrm{g}$ denatured salmon sperm DNA ml ${ }^{-1}, 1250 \mathrm{ng}$ biotinylated probe DNA $\mathrm{ml}^{-1}$ ).

Rapid analysis based on internally transcribed 16S-23S rDNA spacer (ITS1) regions. A rapid DNA isolation method from bacterial colonies was used (Guasp et al., 2000). The ITS1 regions from strains MCS $25^{\mathrm{T}}$, MCS 26 , VKM B-1513 ${ }^{\mathrm{T}}$ and VKM B-1514 were amplified by PCR as described above and using primers designed to anneal at conserved positions in the $3^{\prime}$ and $5^{\prime}$ regions, respectively, of the bacterial $16 \mathrm{~S}$ rRNA and 23S rRNA genes (Abraham et al., 1999; Guasp et al., 2000). Amplified rDNA restriction analysis (ARDRA) of the ITS1 PCR products was performed by digestion with the tetrameric endonuclease TaqI (MBI Fermentas) according to the conditions described elsewhere (Abraham et al., 1999). The existence of possible heterogeneities for each resulting band of the ARDRA fingerprints was examined by single-stranded conformational polymorphism (SSCP), exactly as described previously (Abraham et al., 1999).

Whole-cell fatty acid analysis. Cells were saponified, methylated to fatty acid methyl esters (FAMEs) and extracted as described in detail by Osterhout et al. (1991). FAMEs were analysed on a Hewlett Packard 5890A gas chromatograph. Separation of FAMEs was achieved with a fused-silica capillary column $(25 \mathrm{~m}$ by $0.2 \mathrm{~mm})$ with cross-linked $5 \%$ phenyl methyl silicone (film thickness $0.33 \mu \mathrm{m}$; HP Ultra2). The computer-controlled parameters were the same as those described by Osterhout et al. (1991). The instrument was equipped with a flame-ionization detector and an autosampler (HP 7673). $\mathrm{H}_{2}$ served as carrier gas.

\section{Polar lipid fatty acid analysis}

Lipids were extracted using a modified Bligh-Dyer procedure (Bligh \& Dyer, 1959) as described previously (Vancanneyt et al., 1996). FAMEs were generated and analysed by GC and GC-MS as described previously (Abraham et al., 1999).

${ }^{1} \mathrm{H}$ NMR spectra were recorded in $7: 3 \mathrm{~d}$-chloroform $/ \mathrm{d}_{4}$ methanol at $300 \mathrm{~K}$ on a Bruker ARX-400 NMR spectrometer relative to internal tetramethylsilane using the standard Bruker software.

Fast atom bombardment (FAB)-MS. FAB-MS in the positive and negative modes was performed on the first of two mass spectrometers of a tandem high-resolution instrument in an 
Table 1. Strains used in this study and their origins

\begin{tabular}{|c|c|c|}
\hline Strain & Described here as: & Origin \\
\hline M. maris ATCC $15268^{\mathrm{T}}$ & & Filtered sea water \\
\hline M. maris ATCC $15269 *$ & & Filtered sea water \\
\hline $\operatorname{MCS} 25^{\mathrm{T}}$ & Maricaulis parjimensis sp. nov. MCS $25^{\mathrm{T}}$ & Filtered sea water, Indian Ocean off Goa, India \\
\hline $\operatorname{MCS} 18^{\mathrm{T}}$ & Maricaulis salignorans sp. nov. MSC $18^{\mathrm{T}}$ & $\begin{array}{l}\text { Sea water, Salsbury Point County Park, adjacent to } \\
\text { Hood Canal Bridge, WA, USA }\end{array}$ \\
\hline MCS 10 & Maricaulis sp. MCS 10 & Filtered sea water, Anacortes, WA, USA \\
\hline MCS 11 & Maricaulis sp. MCS 11 & Filtered sea water, Anacortes, WA, USA \\
\hline MCS 26 & Maricaulis sp. MCS 26 & Filtered sea water, Indian Ocean off Goa, India \\
\hline MCS 28 & Maricaulis sp. MCS 28 & $\begin{array}{l}\text { Filtered sea water, Burrard Inlet, Vancouver, British } \\
\text { Columbia, Canada }\end{array}$ \\
\hline MCS 30 & Maricaulis sp. MCS 30 & $\begin{array}{l}\text { Sechelt Peninsula, near Egmont, British Columbia; } \\
\text { scraping from salmon aquaculture net treated with } \\
\text { tributyl tin oxide paint }\end{array}$ \\
\hline MCS 31 & Maricaulis sp. MCS 31 & $\begin{array}{l}\text { Sechelt Peninsula, Wood Bay, British Columbia; from } \\
\text { a sea-water sample taken from a salmon aquaculture } \\
\text { facility }\end{array}$ \\
\hline VKM B-1513 & Maricaulis virginensis sp. nov. VKM B-1513 ${ }^{\mathrm{T}}$ & Deep sea, Virgin Islands (J. Poindexter, strain VC- $5^{\mathrm{T}}$ ) \\
\hline VKM B-1514 & M. virginensis sp. nov. VKM B-1514 & Deep sea, Virgin Islands (J. Poindexter, strain VC-13) \\
\hline $\operatorname{MCS} 6^{\mathrm{T}}$ & Maricaulis washingtonensis sp. nov. MCS $6^{\mathrm{T}}$ & Sea water, Inner Marina, Edmonds, WA, USA \\
\hline
\end{tabular}

* Type strain of C. halobacteroides, a heterotypic synonym of M. maris (Abraham et al., 1999).

$\mathrm{E}_{1} \mathrm{~B}_{1} \mathrm{E}_{2} \mathrm{~B}_{2}$ configuration (JMS-HX/HX110A, JEOL Tokyo) at $10 \mathrm{kV}$ accelerating voltage with the resolution set to 1 : 1000. The JEOL FAB gun was operated at $6 \mathrm{kV}$ with xenon. 3 -Nitrobenzyl alcohol was used as matrix in the positive mode and a mixture of triethanolamine and tetramethylurea (Japanese matrix) in the negative mode.

Tandem MS. Positive and negative daughter-ion spectra were recorded using all four sectors of the tandem mass spectrometer. High-energy collision-induced dissociation (CID) took place in the third field free region. Helium served as the collision gas at a pressure sufficient to reduce the precursor ion signal to $30 \%$ of the original value. The collision cell was operated at ground potential in the positive and negative modes. The resolution of MS2 was set to $1: 1000$. FAB-CID spectra (linked scans of MS2 at constant $\mathrm{B} / \mathrm{E}$ ratio) were recorded with $300 \mathrm{~Hz}$ filtering on a JEOL DA 7000 data system.

Phenotypic characterization. Strains were grown in $20 \mathrm{ml}$ medium PYEM (2 g peptone, 2 g yeast extract, $0.5 \mathrm{~g} \mathrm{NH}_{4} \mathrm{Cl}$, 11 Milli-Q water). After autoclaving and cooling, $5 \mathrm{ml}$ riboflavin $\left(0.2 \mathrm{mg} \mathrm{ml}^{-1}\right)$, filter-sterilized, $2 \mathrm{ml} 50 \%$ glucose (sterile), $1 \mathrm{ml} \mathrm{20 \%} \mathrm{MgSO}_{4}$ (sterile) and $1 \mathrm{ml} 10 \% \mathrm{CaCl}_{2}$ (sterile) were added, amended with $0,5,10,20,30,40,60,80$ or $100 \mathrm{~g} \mathrm{NaCl}^{-1}$. The $\mathrm{OD}_{540}$ of the cell suspension was determined at the beginning of the experiment and after 2 days. The differences between these two measurements were used to determine salt tolerances. Growth was tested at different temperatures in SPYEM medium with the same protocol.

\section{RESULTS}

\section{DNA G + C content}

The $\mathrm{G}+\mathrm{C}$ contents of the DNA of strains MCS $25^{\mathrm{T}}$, MCS $18^{\mathrm{T}}$ and MCS $6^{\mathrm{T}}$ were between 63.0 and $63.3 \mathrm{~mol} \%$. This is close to the value of $62.6 \mathrm{~mol} \%$ determined for $M$. maris ATCC $15268^{\mathrm{T}}$ (Abraham et al., 1999). The $\mathrm{G}+\mathrm{C}$ content for strain VKM B-1513 ${ }^{\mathrm{T}}$ was somewhat higher, $65 \cdot 2 \mathrm{~mol} \%$.

\section{S rDNA sequencing}

Analysis of the nearly complete $16 \mathrm{~S}$ rDNA sequences of the strains investigated in this study revealed three distinct phylogenetic lineages within the genus Maricaulis. The first 16S rDNA lineage consisted of the type species of the genus, M. maris, together with five additional sea-water strains (Fig. 1). The second lineage consisted of a cluster of four strains, MCS $25^{\mathrm{T}}$, MCS 26, VKM B-1513 ${ }^{\mathrm{T}}\left(=\mathrm{VC}-5^{\mathrm{T}}\right)$ and VKM B-1514 (= VC-13), while the third lineage was formed by the two closely related strains MCS $6^{\mathrm{T}}$ and MCS $18^{\mathrm{T}}$.

The four organisms in the second lineage, like the two strains in the third lineage, possessed highly similar $16 \mathrm{~S}$ rDNA sequences. Strains VKM B-1513 ${ }^{\mathrm{T}}$ and VKM B-1514 shared identical 16S rDNA sequences, which were respectively 99.9 and $99.6 \%$ similar to the $16 \mathrm{~S}$ rDNA sequences of MCS 26 and MCS $25^{\mathrm{T}}$. The sole nucleotide difference between the sequences of strains VKM B-1513 ${ }^{\mathrm{T}}$ and VKM B-1514 and that of strain MCS 26 was situated in helix 6, where strain MCS 26 possessed two additional nucleotides in the stem of the helix. The 16S rDNA sequences of strains VKM B-1513 ${ }^{\mathrm{T}}$, VKM B-1514 and MCS 26 possessed $96 \cdot 3 \%$ similarity to the $16 \mathrm{~S}$ rDNA sequence of $M$. maris ATCC $15268^{\mathrm{T}}$, while strain MCS $25^{\mathrm{T}}$ showed $96.6 \%$ sequence similarity to the type species of the genus. The type strain of the type species of Hyphomonas, Hyphomonas polymorpha DSM $2665^{\mathrm{T}}$, the genus most closely related to Maricaulis, revealed 


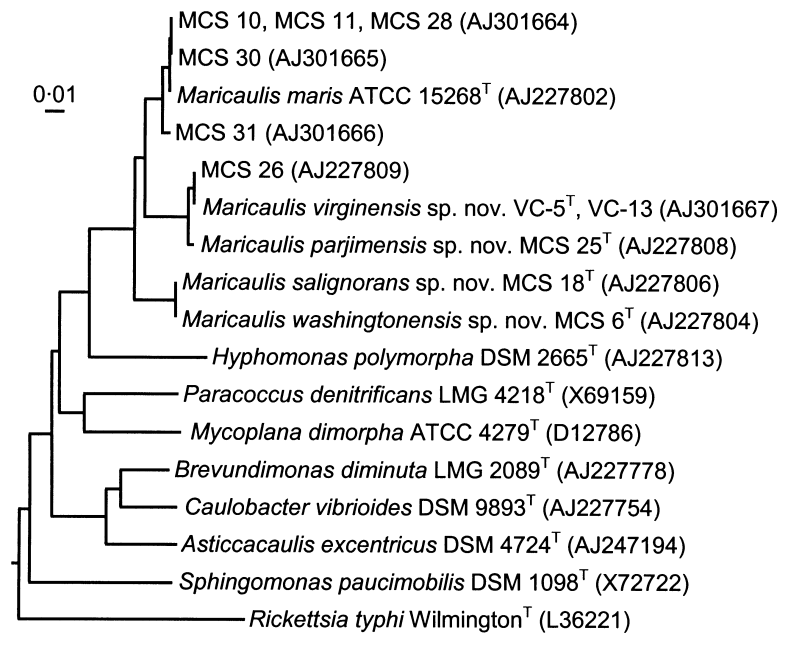

Fig. 1. Unrooted dendrogram based on a comparison of $16 \mathrm{~S}$ rDNA sequences of strains belonging to the genus Maricaulis within the context of the subclass $\alpha$-Proteobacteria. Sequence data for strains of other genera were obtained from the GenBank/EMBL (Stoesser et al., 2001) and/or RDP (Maidak et al., 2001) databases. Accession numbers are given in parentheses. Comamonas testosteroni (RDP) was used as an outgroup (not shown). Bar, 1 nucleotide substitution per 100 bases.

sequence similarity values ranging from $90 \cdot 2$ to $90 \cdot 5 \%$ to the sequences of the strains studied. Within the third 16S rDNA lineage, strains MCS $6^{\mathrm{T}}$ and MCS $18^{\mathrm{T}}$ shared $99.9 \%$ 16S rDNA sequence identity in 1422 homologous nucleotide positions analysed, while the sequence similarities to the most similar 16S rDNA of the validly published species $M$. maris were respectively $96 \cdot 3$ and $96 \cdot 2 \%$. Strains MCS $6^{\mathrm{T}}$ and MCS $18^{\mathrm{T}}$ differed in only one nucleotide, at position 156 (Escherichia coli numbering) in helix 9 (Neefs et al., 1991), where a cytosine in the sequence of MCS $6^{\mathrm{T}}$ was replaced by a thymidine in the sequence of MCS $18^{\mathrm{T}}$. This substitution resulted in a G-T pairing in the secondary structure of helix 9 of MCS $18^{\mathrm{T}}$, instead of a G-C pair in the secondary structure of MCS $6^{\mathrm{T}}$. The $16 \mathrm{~S}$ rDNA

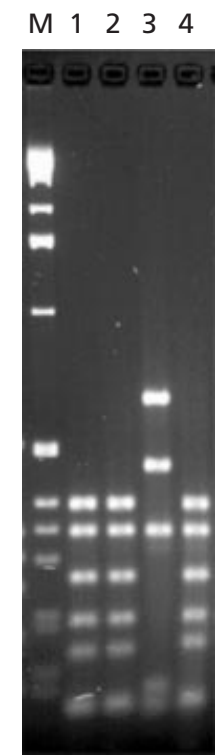

Fig. 2. Fingerprints generated after Taql restriction analysis of PCR-amplified ITS1 of the different strains of Maricaulis in 3.0\% agarose gels. Lanes: $M, 1 \mathrm{~kb}$ DNA molecular mass ladder (Gibco); 1, Maricaulis strain VKM B-1513 ${ }^{\top} \quad\left(=\mathrm{VC}-5^{\top}\right) ; 2$, Maricaulis strain VKM B-1514 (=VC-13); 3, Maricaulis strain MCS $25^{\top} ; 4$, Maricaulis strain MCS 26.

similarity values of these two strains to strains of the second lineage ranged from $94 \cdot 3$ to $94 \cdot 7 \%$.

\section{DNA-DNA hybridization}

The results of DNA-DNA hybridizations of Maricaulis strains are listed in Table 2. Strains VKM B-1513 ${ }^{\mathrm{T}}$ and VKM B-1514 were observed to be highly related $(83 \%)$ and both strains showed close relatedness to strain MCS $26(70 \%)$. Strain MCS $25^{\mathrm{T}}$ is separated from all other strains. As described previously (Abraham et al., 1999), M. maris (C. maris) ATCC $15268^{\mathrm{T}}$ and C. halobacteroides ATCC $15269^{\mathrm{T}}$ are highly related $(92 \%)$ and their names are

Table 2. DNA-DNA hybridization of Maricaulis strains

Values for DNA-DNA hybridization are means with standard deviations given in parentheses. ND, Not determined.

\begin{tabular}{|c|c|c|c|c|c|c|c|c|c|}
\hline \multirow[t]{2}{*}{ Strain } & \multirow{2}{*}{$\begin{array}{c}G+C \text { content } \\
(\mathrm{mol} \%)\end{array}$} & \multicolumn{8}{|c|}{ DNA-DNA hybridization with DNA from: } \\
\hline & & 1 & 2 & 3 & 4 & 5 & 6 & 7 & 8 \\
\hline 1. M. maris ATCC $15268^{\mathrm{T}}$ & $63 \cdot 3$ & 100 & & & & & & & \\
\hline 2. M. maris ATCC 15269 & $63 \cdot 2$ & 92 & 100 & & & & & & \\
\hline 3. Maricaulis sp. MCS $25^{\mathrm{T}}$ & $63 \cdot 0$ & $23(1)$ & ND & 100 & & & & & \\
\hline 4. Maricaulis sp. MCS 26 & $64 \cdot 9$ & ND & ND & $28(13)$ & 100 & & & & \\
\hline 5. Maricaulis sp. VKM B-1513 ${ }^{\mathrm{T}}$ & $65 \cdot 2$ & ND & ND & $32(11)$ & $70(16)$ & 100 & & & \\
\hline 6. Maricaulis sp. VKM B-1514 & $65 \cdot 3$ & $33(13)$ & $27(17)$ & $28(4)$ & ND & $83(11)$ & 100 & & \\
\hline 7. Maricaulis sp. MCS $6^{\mathrm{T}}$ & $63 \cdot 0$ & ND & ND & $21(6)$ & $25(5)$ & $25(2)$ & $24(5)$ & 100 & \\
\hline 8. Maricaulis sp. MCS $18^{\mathrm{T}}$ & $63 \cdot 1$ & $32(15)$ & $19(15)$ & $18(3)$ & $17(8)$ & $23(2)$ & $19(1)$ & $59(9)$ & 100 \\
\hline
\end{tabular}


Table 3. Fatty acid content of whole-cell hydrolysates of Maricaulis strains

Values are percentages of total fatty acids. Strains: 1, Maricaulis sp. MCS 10;2, Maricaulis sp. MCS 11; 3, Maricaulis sp. MCS 28; 4, M. maris ATCC 15268 $;$; , M. maris ATCC 15269; 6, Maricaulis sp. MCS 26; 7, M. virginensis sp. nov. VKM B-1513 ${ }^{\mathrm{T}}$; 8, M. virginensis sp. nov. VKM B-1514; 9, M. parjimensis sp. nov. MCS 25 $; 10, M$. salignorans sp. nov. MCS $18^{\mathrm{T}} ; 11, M$. washingtonensis sp. nov. MCS $6^{\mathrm{T}}$. Strains are listed in the order of Fig. 1. Only fatty acids accounting for more than $1 \cdot 0 \%(\mathrm{mean}$ amount) of the total fatty acids are indicated. tr, Trace amount $(<1.0 \%) ;-$, not detected.

\begin{tabular}{|c|c|c|c|c|c|c|c|c|c|c|c|}
\hline Fatty acid & 1 & 2 & 3 & 4 & 5 & 6 & 7 & 8 & 9 & 10 & 11 \\
\hline $11: 0$ iso $3 \mathrm{OH}$ & $2 \cdot 1$ & $2 \cdot 8$ & $2 \cdot 0$ & $2 \cdot 6$ & $3 \cdot 8$ & $1 \cdot 6$ & $5 \cdot 4$ & $5 \cdot 0$ & $\operatorname{tr}$ & $\operatorname{tr}$ & $\operatorname{tr}$ \\
\hline $12: 03 \mathrm{OH}$ & - & - & - & - & - & $\operatorname{tr}$ & - & - & - & - & - \\
\hline $15: 0$ & $\operatorname{tr}$ & $\operatorname{tr}$ & $\operatorname{tr}$ & $\operatorname{tr}$ & $\operatorname{tr}$ & - & - & - & - & $\operatorname{tr}$ & $\operatorname{tr}$ \\
\hline $16: 0$ & $14 \cdot 0$ & $14 \cdot 0$ & $13 \cdot 0$ & $17 \cdot 0$ & $16 \cdot 0$ & $7 \cdot 6$ & $9 \cdot 8$ & $12 \cdot 3$ & $3 \cdot 6$ & $8 \cdot 9$ & $11 \cdot 0$ \\
\hline Summed feature $4^{*}$ & $3 \cdot 0$ & $3 \cdot 2$ & $3 \cdot 2$ & $6 \cdot 6$ & $6 \cdot 0$ & 1.9 & $2 \cdot 4$ & $3 \cdot 9$ & $2 \cdot 2$ & $2 \cdot 6$ & $3 \cdot 0$ \\
\hline $16: 1 \omega 9 c$ & $\operatorname{tr}$ & $\operatorname{tr}$ & $\operatorname{tr}$ & $1 \cdot 0$ & $\operatorname{tr}$ & - & - & - & - & $\operatorname{tr}$ & $\operatorname{tr}$ \\
\hline $17: 0$ & $11 \cdot 0$ & $11 \cdot 0$ & $14 \cdot 0$ & $5 \cdot 3$ & $6 \cdot 2$ & $11 \cdot 6$ & $15 \cdot 3$ & $13 \cdot 7$ & $7 \cdot 0$ & $8 \cdot 7$ & $9 \cdot 0$ \\
\hline $17: 1 \omega 6 c$ & $1 \cdot 7$ & $1 \cdot 0$ & $1 \cdot 6$ & $\operatorname{tr}$ & $\operatorname{tr}$ & $3 \cdot 2$ & $1 \cdot 3$ & - & $1 \cdot 8$ & $1 \cdot 1$ & $1 \cdot 0$ \\
\hline $17: 1 \omega 8 c$ & $6 \cdot 6$ & $6 \cdot 6$ & $8 \cdot 3$ & $4 \cdot 0$ & $4 \cdot 8$ & $8 \cdot 0$ & $9 \cdot 6$ & $10 \cdot 0$ & $4 \cdot 7$ & $10 \cdot 0$ & $10 \cdot 0$ \\
\hline $17: 0$ iso & $12 \cdot 0$ & $6 \cdot 7$ & $11 \cdot 1$ & $7 \cdot 7$ & $7 \cdot 1$ & $4 \cdot 8$ & $6 \cdot 9$ & $5 \cdot 4$ & $1 \cdot 7$ & $10 \cdot 8$ & $9 \cdot 6$ \\
\hline $17: 1$ iso $\omega 9 c$ & $18 \cdot 9$ & $16 \cdot 7$ & $19 \cdot 0$ & $17 \cdot 4$ & $16 \cdot 9$ & $6 \cdot 1$ & $13 \cdot 8$ & $13 \cdot 5$ & $3 \cdot 9$ & $28 \cdot 0$ & $22 \cdot 4$ \\
\hline $18: 0$ & $1 \cdot 0$ & $1 \cdot 4$ & $1 \cdot 0$ & $1 \cdot 1$ & $1 \cdot 1$ & $4 \cdot 6$ & $4 \cdot 2$ & $3 \cdot 8$ & $7 \cdot 9$ & $\operatorname{tr}$ & $\operatorname{tr}$ \\
\hline Summed feature 7 & $19 \cdot 0$ & $25 \cdot 6$ & $17 \cdot 2$ & $24 \cdot 5$ & $24 \cdot 0$ & $33 \cdot 1$ & $13 \cdot 0$ & $18 \cdot 1$ & $47 \cdot 9$ & $12 \cdot 9$ & $16 \cdot 2$ \\
\hline $18: 1 \omega 9 c$ & $4 \cdot 5$ & $5 \cdot 4$ & $4 \cdot 1$ & $6 \cdot 4$ & $6 \cdot 2$ & $5 \cdot 1$ & $3 \cdot 4$ & $4 \cdot 2$ & $6 \cdot 0$ & $7 \cdot 7$ & $10 \cdot 7$ \\
\hline ECL $18 \cdot 080 \dagger$ & $\operatorname{tr}$ & $\operatorname{tr}$ & $\operatorname{tr}$ & $1 \cdot 6$ & $1 \cdot 6$ & $1 \cdot 4$ & $2 \cdot 9$ & $2 \cdot 1$ & $\operatorname{tr}$ & $1 \cdot 0$ & $\operatorname{tr}$ \\
\hline ECL 18.424 & 1.9 & 1.9 & 1.9 & $1 \cdot 3$ & $1 \cdot 3$ & $5 \cdot 4$ & $5 \cdot 7$ & $4 \cdot 2$ & $2 \cdot 3$ & $1 \cdot 8$ & $1 \cdot 3$ \\
\hline ECL 18.797 & $\operatorname{tr}$ & $\operatorname{tr}$ & $\operatorname{tr}$ & $\operatorname{tr}$ & $\operatorname{tr}$ & $3 \cdot 9$ & $2 \cdot 6$ & $2 \cdot 2$ & $4 \cdot 9$ & $\operatorname{tr}$ & $\operatorname{tr}$ \\
\hline
\end{tabular}

* Summed features consist of one or more fatty acids that could not be separated by the Microbial Identification System. Summed

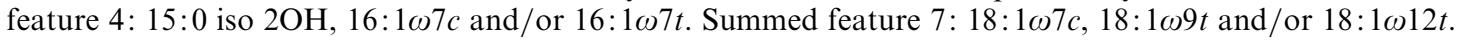

$\dagger$ Unidentified fatty acids with equivalent chain length (ECL) given.

synonyms, and they are not related to any of the other strains studied.

\section{ITS1 analysis}

ITS1 analysis was applied as a rapid bacterial identification and typing tool in order to confirm the close relatedness among four Maricaulis strains. The utility of ITS1 for the clarification of the phylogenetic positions of these Maricaulis strains has been demonstrated by the ability of these nucleic acid regions to differentiate closely related organisms at the species level (Guasp et al., 2000). The strains submitted to this high-resolution analysis were strains MCS 26, MCS $25^{\mathrm{T}}$, VKM B-1513 ${ }^{\mathrm{T}}\left(=\mathrm{VC}-5^{\mathrm{T}}\right)$ and VKM B-1514 (= VC-13). For all strains, a single ITS1 PCR product was obtained. Agarose gel electrophoresis mobility differences between the strains were not clearly detected after this first step (data not shown). Each of the four strains displayed a single agarose gel band corresponding to a PCR product of between 1.6 and $2.0 \mathrm{~kb}$, of which approximately $0.6 \mathrm{~kb}$ comprises the $16 \mathrm{~S}$ rDNA 3 '-region and nearly $0.5 \mathrm{~kb}$ comprises the $23 \mathrm{~S}$ rDNA 5 -region; the difference ( $\sim 0.5$ to $\sim 0.9 \mathrm{~kb})$ comprises the ITS1 regions. As a second step, the individual ITS1 PCR products of the four strains were subjected to TaqI ARDRA presumptive fingerprint differentiation analysis. Strains MCS 26, VKM B$1513^{\mathrm{T}}$ and VKM B-1514 showed identical ARDRA patterns, confirming a close phylogenetic relationship among these three strains (Fig. 2). A clearly distinct fingerprint was observed for strain MCS $25^{\mathrm{T}}$, sharing only two bands with the fingerprints observed for the remaining strains (Fig. 2). These results were supported by SSCP for evaluation of the existence of sequence heterogeneities for each restriction band observed for strains sharing the same ARDRA pattern, i.e. MCS $26, \mathrm{VKM} \mathrm{B}-1513^{\mathrm{T}}\left(=\mathrm{VC}-5^{\mathrm{T}}\right)$ and VKM B-1514 (=VC-13). Identical SSCP band patterns were obtained for strains VKM B-1513 ${ }^{\mathrm{T}}$ and VKM B-1514, while some bands in the SSCP pattern for strain MCS 26 showed subtle differences in mobility, directly related to differences in single-strand conformations in comparison with strains VKM B$1513^{\mathrm{T}}$ and VKM B-1514 (data not shown).

\section{Analysis of FAMEs}

The cellular fatty acid compositions of Maricaulis type strains and related strains are shown in Table 3. Strains VKM B-1513 ${ }^{\mathrm{T}}$ and VKM B-1514 possessed considerable amounts of $11: 0$ iso $3 \mathrm{OH}$, a fatty acid that was found in only trace amounts in strains MCS $18^{\mathrm{T}}$ and MCS $6^{\mathrm{T}}$. Strains MCS 26 and MCS $25^{\mathrm{T}}$ differed from all other Maricaulis strains analysed so far in possessing higher contents of the unidentified fatty acids ECL 18.424 and ECL 18.797. Strains MCS $18^{\mathrm{T}}$ and MCS $6^{\mathrm{T}}$ possessed the largest amounts of all 
Table 4. Glycolipids identified in Maricaulis strains by (-)-FAB CID-MS

\begin{tabular}{|c|c|c|c|}
\hline Mass & Туре* & Compound & Strain(s) \\
\hline 730 & MGDOx & 1-C16:0-2-C15:0-glucuronyl-glycerol & MCS 31 \\
\hline 742 & MGDOx & 1-C16:0-2-C16:1-glucuronyl-glycerol & MCS 28 \\
\hline 744 & MGDOx & 1-C15:0-2-C17:0-glucuronyl-glycerol & MCS 31 \\
\hline 744 & MGD & 1-C17:0-2-C16:0-glucosyl-glycerol & MCS 31 \\
\hline 756 & MGDOx & 1-C17:1-2-C16:0-glucuronyl-glycerol & MCS 28 \\
\hline 766 & MGDOx & 1-C18:1-2-C16:2-glucuronyl-glycerol & MCS 28 \\
\hline 770 & MGDOx & 1-C18:1-2-C16:0-glucuronyl-glycerol & MCS 28 \\
\hline 770 & MGD & 1-C19:1-2-C16:0-glucosyl-glycerol & MCS 28 \\
\hline 770 & MGDOx & 1-C17:1-2-C17:0-glucuronyl-glycerol & MCS 28 \\
\hline 770 & MGD & 1-C17:0-2-C18:1-glucosyl-glycerol & MCS 28 \\
\hline 772 & MGDOx & 1-C18:0-2-C16:0-glucuronyl-glycerol & MCS 28 \\
\hline 780 & MGDOx & 1-C17:2-2-C18:1-glucuronyl-glycerol & MCS 28 \\
\hline 780 & MGDOx & 1-C17:1-2-C18:2-glucuronyl-glycerol & MCS 28 \\
\hline 780 & MGD & 1-C18:2-2-C18: 1-glucosyl-glycerol & MCS 28 \\
\hline 782 & MGDOx & 1-C17:1-2-C18:1-glucuronyl-glycerol & $\begin{array}{c}\operatorname{MCS} 6^{\mathrm{T}}, \\
\operatorname{MCS} 28\end{array}$ \\
\hline 784 & MGDOx & 1-C19:1-2-C16:0-glucuronyl-glycerol & MCS 28 \\
\hline 784 & MGDOx & 1-C18:0-2-C17:1-glucuronyl-glycerol & MCS 28 \\
\hline 784 & MGDOx & 1-C18:1-2-C17:0-glucuronyl-glycerol & MCS 28 \\
\hline 796 & MGDOx & 1-C18:1-2-C18:1-glucuronyl-glycerol & MCS 28 \\
\hline 798 & MGDOx & 1-C18:1-2-C18:0-glucuronyl-glycerol & MCS 10 \\
\hline 798 & MGD & 1-C19:0-2-C18:1-glucosyl-glycerol & MCS 10 \\
\hline 812 & MGDOx & 1-C19:0-2-C18:1-glucuronyl-glycerol & MCS 28 \\
\hline
\end{tabular}

* MGD, 1,2-Diacyl-glucosyl-glycerol; MGDOx, 1,2-diacyl-glucuronyl-glycerol.

Maricaulis strains studied of $17: 1 \omega 8 c$ and $17: 1$ iso $\omega 9 c$.

\section{MS analysis of polar lipids}

A number of unique glycolipids were characterized from the polar lipid fraction of Maricaulis strains by MS and ${ }^{1} \mathrm{H}$ NMR. The NMR spectra revealed that the glycolipids all belong to the $\alpha$-glucosyl and $\alpha$ glucuronosyl diacyl glycerol types. The structures of the individual compounds were elucidated by FABand CID-MS in a tandem mass spectrometer. The mass-spectrometric behaviour of these compounds in the negative ionization mode strongly resembles that of phospholipids (Murphy \& Harrison, 1994; Abraham et al., 1997). They show distinct $[\mathrm{M}-\mathrm{H}]^{-}$ ions. CID of $[\mathrm{M}-\mathrm{H}]^{-}$ions yields abundant carboxylate anions from both the $s n-1$ and $s n-2$ position of the glycerol backbone, allowing the identification of the glycolipid species. The relative abundance of the carboxylate anions may provide evidence for the relative positions of the two acyl functions. By analogy to phospholipids, the loss of the $s n$-2-acyl position may be favoured, thus yielding a more abundant carboxylate anion (Murphy \& Harrison, 1994). In the Maricaulis strains studied, $\alpha$-glucuronosyl diacyl glycerols are more abundant and, as can be seen by the compounds identified, exist in a broader variety than the $\alpha$-glucosyl diacyl glycerols (Table 4 ).
The polar lipids of Maricaulis strains VKM $1513^{\mathrm{T}}$ and VKM 1514 consist mainly of sulfolipids (Table 5). They were identified by MS as sulfoquinovosyl diacyl glycerols (SQDG) (Abraham et al., 1997). Besides the known compounds 1-3 (Table 6), strains VKM $1513^{\mathrm{T}}$ and VKM 1514 also contained novel SQDGs in the mass range $m / z$ 848-862. They were identified as compounds 4-8 (Table 6) by using tandem MS and the fragmentation patterns described previously (Abraham et al., 1997).

The patterns of polar lipids reveal two groups of Maricaulis strains, one comprising the type species, $M$. maris, and strains MCS $6^{\mathrm{T}}$, MCS 10, MCS 11, MCS $18^{\mathrm{T}}$, MCS 28, MCS 30 and MCS 31, characterized by a number of different glycolipids, sometimes together with taurineamides (Batrakov et al., 1996), while the other group, containing Maricaulis strains MCS $25^{\mathrm{T}}$, MCS 26, VKM B-1513 ${ }^{\mathrm{T}}$ and VKM B-1514, has large amounts of sulfolipids of the SQDG type.

\section{Phenotypic characterization}

All Maricaulis strains grew best with salt concentrations between 20 and $80 \mathrm{~g} \mathrm{NaCl}^{-1}$. Maricaulis strain MCS $18^{\mathrm{T}}$ also grew without salt, but with a slightly reduced growth rate. Maricaulis strain MCS $6^{\mathrm{T}}$ was more sensitive than strain MCS $18^{\mathrm{T}}$ to high salt concentrations and showed reduced growth at salt 
Table 5. Polar lipids identified by MS in Maricaulis strains

Strains: 1, Maricaulis sp. MCS 10;2, Maricaulis sp. MCS 11;3, Maricaulis sp. MCS 28; 4, Maricaulis sp. MCS 30; 5, M. maris ATCC $15268^{\mathrm{T}} ; 6$, M. maris ATCC 15269; 7, Maricaulis sp. MCS 31; 8, Maricaulis sp. MCS 26; 9, M. virginensis sp. nov. VKM B-1513 $; 10$, M. virginensis sp. nov. VKM B-1514; 11, M. parjimensis sp. nov. MCS $25^{\mathrm{T}} ; 12$, M. salignorans $\mathrm{sp}$. nov. MCS $18^{\mathrm{T}}$; 13, M. washingtonensis sp. nov. MCS $6^{\mathrm{T}}$. Strains are listed in the order of Fig. 1.

\begin{tabular}{|c|c|c|c|c|c|c|c|c|c|c|c|c|c|c|c|c|}
\hline \multirow[t]{2}{*}{ Mass } & \multirow[t]{2}{*}{ Type* } & \multicolumn{2}{|c|}{ Fatty acid } & \multicolumn{13}{|c|}{ Detected in strain $: \dagger$} \\
\hline & & $\mathrm{R}_{1} \mathrm{COOH}$ & $\mathrm{R}_{2} \mathrm{COOH}$ & 1 & 2 & 3 & 4 & 5 & 6 & 7 & 8 & 9 & 10 & 11 & 12 & 13 \\
\hline 720 & PG & $18: 1$ & $14: 0$ & & & $\mathrm{~F}$ & & $\mathrm{~F}$ & & & & & & & & \\
\hline 730 & GL & & & & & & & & & $\mathrm{C}$ & & & & & & \\
\hline 734 & PG & $18: 1$ & $15: 0$ & & & & & $\mathrm{~F}$ & & & & & & & & \\
\hline 742 & GL & & & & $\mathrm{F}$ & $\mathrm{C}$ & & & & & & & & & & $\mathrm{C}$ \\
\hline 744 & GL & & & & & & & & & $\mathrm{C}$ & & & & & & \\
\hline 746 & PG & $18: 1$ & $16: 1$ & & & & & & $\mathrm{~F}$ & & & & & & & \\
\hline 748 & PG & $18: 1$ & $16: 0$ & & & $\mathrm{~F}$ & & $\mathrm{~F}$ & $\mathrm{~F}$ & & & & & & & \\
\hline 750 & PG & $19: 0$ & $15: 0$ & & & & & $\mathrm{~F}$ & & & & & & & & \\
\hline 756 & GL & & & $\mathrm{F}$ & $\mathrm{F}$ & $\mathrm{C}$ & $\mathrm{F}$ & & & $\mathrm{F}$ & & & & & $\mathrm{F}$ & $\mathrm{F}$ \\
\hline 762 & PG & $19: 1$ & $16: 0$ & & & & & $\mathrm{~F}$ & & & & & & & & \\
\hline 768 & GL & & & & $\mathrm{F}$ & & & & & & & & & & & \\
\hline 770 & GL & & & $\mathrm{F}$ & $\mathrm{F}$ & $\mathrm{C}$ & $\mathrm{F}$ & & & $\mathrm{F}$ & & $\mathrm{C}$ & & & $\mathrm{F}$ & $\mathrm{F}$ \\
\hline 772 & GL & & & & & $\mathrm{C}$ & & & & & & $\mathrm{F}$ & & & $\mathrm{F}$ & \\
\hline 774 & PG & $18: 1$ & $18: 1$ & & & $\mathrm{C}$ & & & $\mathrm{F}$ & & & & & & & \\
\hline 780 & GL & & & & & $\mathrm{C}$ & & & & & & & & & & \\
\hline 782 & GL & & & $\mathrm{F}$ & $\mathrm{F}$ & $\mathrm{C}$ & & & & & & & $\mathrm{F}$ & & & $\mathrm{C}$ \\
\hline 784 & GL & & & $\mathrm{F}$ & $\mathrm{F}$ & $\mathrm{C}$ & $\mathrm{F}$ & $\mathrm{F}$ & $\mathrm{F}$ & $\mathrm{F}$ & & $\mathrm{C}$ & $\mathrm{F}$ & & $\mathrm{F}$ & $\mathrm{F}$ \\
\hline 796 & GL & & & $\mathrm{F}$ & $\mathrm{F}$ & $\mathrm{C}$ & & & & & & & & & $\mathrm{F}$ & $\mathrm{F}$ \\
\hline 798 & GL & & & $\mathrm{C}$ & & $\mathrm{C}$ & & & & & & $\mathrm{C}$ & $\mathrm{F}$ & $\mathrm{F}$ & & \\
\hline 812 & GL & & & & & $\mathrm{C}$ & & & & & & & & & & \\
\hline 820 & SQDG & $18: 1$ & $16: 0$ & $\mathrm{~F}$ & $\mathrm{~F}$ & $\mathrm{C}$ & & $\mathrm{F}$ & $\mathrm{F}$ & & $\mathrm{F}$ & $\mathrm{F}$ & & $\mathrm{F}$ & $\mathrm{F}$ & $\mathrm{F}$ \\
\hline 834 & SQDG & $18: 1$ & $17: 0$ & $\mathrm{~F}$ & & $\mathrm{C}$ & & $\mathrm{F}$ & $\mathrm{F}$ & & $\mathrm{F}$ & $\mathrm{F}$ & $\mathrm{F}$ & $\mathrm{F}$ & & \\
\hline 846 & SQDG & $18: 1$ & $18: 1$ & $\mathrm{~F}$ & & $\mathrm{C}$ & & $\mathrm{F}$ & & & $\mathrm{F}$ & $\mathrm{C}$ & & $\mathrm{F}$ & & $\mathrm{F}$ \\
\hline 848 & SQDG & $18: 1$ & $18: 0$ & & & & & & & & $\mathrm{~F}$ & $\mathrm{C}$ & $\mathrm{C}$ & & & \\
\hline 850 & SQDG & $19: 0$ & $17: 0$ & & & & & & & & & $\mathrm{C}$ & & & & \\
\hline 860 & SQDG & $18: 1$ & $19: 1$ & & & & & & & & & $\mathrm{C}$ & $\mathrm{F}$ & & & \\
\hline 862 & SQDG & $19: 1$ & $18: 0$ & & & & & & & & & $\mathrm{C}$ & $\mathrm{F}$ & & & \\
\hline 878 & Tau & $18: 1$ & $16: 0$ & $\mathrm{~F}$ & & $\mathrm{C}$ & & & $\mathrm{F}$ & & & & & & & \\
\hline 904 & Tau & $18: 1$ & $18: 1$ & $\mathrm{~F}$ & $\mathrm{~F}$ & $\mathrm{C}$ & & & & & & & & & & \\
\hline
\end{tabular}

* GL, Glycolipid, either glucosyl- or glucuronosyl-diacyl-glycerol or both (see Table 4 for identification of the compounds); PG, phosphatidyl glycerol; SQDG, sulfoquinovosyl diacylglycerol; Tau, 1,2-diacyl-3- $\alpha$-D-glucuronopyranosyl-sn-glycerol taurineamide. $\dagger \mathrm{F}$, Ion in negative FAB-MS; C, identified by CID-MS.

Table 6. Sulfolipids found in Maricaulis strain VKM B$1513^{\top}$

\begin{tabular}{|lcc|}
\hline Compound & Mass & Lipid \\
\hline 1 & 820 & 1-C18:1-2-C16:0-quinovosyl-glycerol \\
2 & 834 & $1-\mathrm{C} 18: 1-2-\mathrm{C} 17: 0$-quinovosyl-glycerol \\
3 & 846 & $1-\mathrm{C} 18: 1-2-\mathrm{C} 18: 1$-quinovosyl-glycerol \\
4 & 848 & $1-\mathrm{C} 18: 1-2-\mathrm{C} 18: 0$-quinovosyl-glycerol \\
5 & 850 & $1-\mathrm{C} 19: 0-2-\mathrm{C} 17: 0$-quinovosyl-glycerol \\
6 & 850 & $1-\mathrm{C} 18: 0-2-\mathrm{C} 18: 0$-quinovosyl-glycerol \\
7 & 860 & 1-C18:1-2-C19:1-quinovosyl-glycerol \\
8 & 862 & $1-\mathrm{C} 19: 1-2-\mathrm{C} 18: 0$-quinovosyl-glycerol \\
\hline
\end{tabular}

concentrations above $60 \mathrm{~g} \mathrm{1}^{-1}$. Growth of Maricaulis strain MCS 26 was reduced somewhat at 5-10 and 80-100 g NaCl ${ }^{-1}$, while growth without salt was relatively slow. While tolerance of $100 \mathrm{~g} \mathrm{NaCl}^{-1}$ is shared with $M$. maris, the latter could not grow without salt (Abraham et al., 1999). Maricaulis strains VKM $1513^{\mathrm{T}}$ and VKM 1514 could not grow on PYE medium without $\mathrm{NaCl}$, but optimal growth occurred between 5 and $100 \mathrm{~g} \mathrm{NaCl}^{-1}$.

All Maricaulis strains grew best at temperatures between 30 and $40^{\circ} \mathrm{C}$. Maricaulis strain VKM B$1513^{\mathrm{T}}$ grew best between 20 and $40{ }^{\circ} \mathrm{C}$ and even showed some growth at $10^{\circ} \mathrm{C}$. Similar behaviour was observed 
for Maricaulis strain MCS $18^{\mathrm{T}}$, although Maricaulis strain MCS $6^{\mathrm{T}}$ grew considerably faster at $10^{\circ} \mathrm{C}$ and even showed some growth at $4{ }^{\circ} \mathrm{C}$, at which temperature most of the other Maricaulis strains could not grow. Maricaulis strain MCS 26 grew best at $40{ }^{\circ} \mathrm{C}$, showed somewhat reduced growth at $30^{\circ} \mathrm{C}$ and showed almost no growth at $10{ }^{\circ} \mathrm{C}$.

\section{DISCUSSION}

The branching order and evolutionary distances, represented by the branch lengths in Fig. 1, suggested that the sea-water caulobacteria of this study belong to the genus Maricaulis. Fig. 1 also revealed that strains described as Maricaulis spp. constitute distinct lineages, and the novel species described in this paper comprise two distinct groups that are clearly separate from the type species of Maricaulis, M. maris. Whereas the evolutionary distances imply the systematic distinction of MCS $6^{\mathrm{T}}$ and MCS $18^{\mathrm{T}}$ in one group and VKM B-1513 ${ }^{\mathrm{T}}$, VKM B-1514, MCS $25^{\mathrm{T}}$ and MCS 26 in the other, the species delineation within these two groups is not so significant by $16 \mathrm{~S}$ rDNA analysis.

In a previous study (Abraham et al., 1999), $C$. halobacteroides ATCC $15269^{\mathrm{T}}$ was shown to be synonymous with Maricaulis (Caulobacter) maris ATCC $15268^{\mathrm{T}}$, based on lipid and fatty acid content, 16S rDNA analysis, ITS1 patterns, DNA-DNA hybridization and the very small number of observable phenotypic differences. Although the 16S rDNA sequences of ATCC $15269^{\mathrm{T}}$ and ATCC $15268^{\mathrm{T}}$ were observed to be identical, this alone would not have justified merging these two species. Sequence comparison of $16 \mathrm{~S}$ rRNA genes, in general, determines relationships between bacterial genera and is also used widely to resolve intrageneric relationships. However, the genetic standard for species delineation in bacterial systematics is DNA-DNA hybridization (Wayne et al., 1987). Although good correlations have been shown between $16 \mathrm{~S}$ sequence similarity and DNADNA hybridization values (Stackebrandt \& Goebel, 1994; Keswani \& Whitman, 2001), examples exist where 16S rRNA gene analyses have failed to distinguish sufficiently between species that are clearly separate by phenotypic traits and hybridization values (Hauben et al., 1997). In this study, we observed only a single nucleotide difference between Maricaulis strains MCS $6^{\mathrm{T}}$ and MCS $18^{\mathrm{T}}$. Almost-identical 16S rDNA sequences have also been found between species of Pseudomonas (Anzai et al., 2000) and, although DNA-DNA hybridization experiments of the respective species pairs have not yet been published, it became apparent from the original publications that significant differences existed in the metabolic traits of these organisms (Elomari et al., 1997; Nishimori et al., 2000).

The same situation apparently exists in the second cluster within Maricaulis. The 16S rDNA sequences of strains VKM B-1513 $/$ VKM B-1514 and MCS 26 differed only in the deletion of one base pair in the stem of helix 6 in the 16S rRNA genes of strains VKM B$1513^{\mathrm{T}}$ and VKM B-1514. Again, these strains are genetically highly related, and the definition of distinct taxa could only be justified in combination with results obtained from other methods taken together. Strain MCS $25^{\mathrm{T}}$ could be discriminated genetically from MCS 26 and VKM B-1513 ${ }^{\mathrm{T}}$ with greater confidence. The lower 16S rDNA similarity values of strain MCS $25^{\mathrm{T}}$ to VKM B- $1513^{\mathrm{T}}$ and to MCS 26 were reflected in relatively larger differences in all methods applied in this study. The five marine strains that cluster with $M$. maris ATCC $15268^{\mathrm{T}}$ (Fig. 1) possessed highly similar $16 \mathrm{~S}$ rDNA sequences ( $>99 \cdot 2 \%$ sequence similarity) but, judging from the results presented in this study, may represent three additional species of Maricaulis.

Inasmuch as differences were not observed in the number (a single band was detected for all the strains) and length of the amplified ITS1 (differences in mobility were also not appreciated), we applied a progressive method where higher levels of resolution were achieved. Such a consecutive ARDRA-SSCP identification analysis, applied successfully in this and previous studies (Guasp et al., 2000), permitted us to confirm a clear differentiation, presumably at the species level, in three molecular typing groups. A pattern-based cluster was obtained for strains VKM B-1513 ${ }^{\mathrm{T}}$ (=VC- $\left.5^{\mathrm{T}}\right)$ and VKM B-1514 (= VC-13), which were not differentiated even after SSCP analysis. Maricaulis strain MCS 26 was closely related to those strains described above, and this was demonstrated by the fact that the three strains shared the same ARDRA pattern, although they were differentiated after the SSCP analysis, in which band heterogeneities were detected (data not shown). After ARDRA analysis, Maricaulis strain MCS $25^{\mathrm{T}}$ already showed a clearly distinct pattern, suggesting a more distant position from the other strains. Consequently, the results obtained by ITS1 analysis suggest the clear existence of a Maricaulis species represented by strains VKM B$1513^{\mathrm{T}}$ and VKM B-1514, and these results were strongly supported by additional data obtained from the other approaches used in this study. However, although ITS1 analysis suggested a differentiation of strain MCS 26 from strains VKM B-1513 ${ }^{\mathrm{T}}$ and VKM B-1514, an even clearer differentiation was obtained of strain MCS $25^{\mathrm{T}}$ from all the other strains, suggesting the inclusion of this strain in a clearly differentiated ITS1 molecular typing group, i.e. in a distinct species.

The DNA-DNA hybridization value between strains VKM B- $1513^{\mathrm{T}}$ and MCS 26 was $70 \%$, with a rather large error $(16 \%)$. This value is exactly at the limit where two strains, by definition, belong to the same species. However, strain MCS 26 differed from strain VKM B-1513 ${ }^{\mathrm{T}}$ by its composition of polar lipids (reduced number of sulfolipids), its fatty acid composition (less 11:0 iso $3 \mathrm{OH}$ ), the lack of growth at $20{ }^{\circ} \mathrm{C}$ and some growth without $\mathrm{NaCl}$. It can also be differentiated from the other strains by different $16 \mathrm{~S}$ rRNA gene sequences and in the ITS1 region. All these 
differences in largely unrelated properties taken together do not allow an unambiguous inclusion of these strains in the same species. Although DNADNA hybridization showed that strains MCS $6^{\mathrm{T}}$ and MCS $18^{\mathrm{T}}$ are closely related (59\%), they represent distinct species.

The characteristic fatty acids found for the type species of Maricaulis, M. maris, and related strains were also found in the strains analysed in this study (Abraham et al., 1999). The fatty acids $12: 13 \mathrm{OH}$ and 14:0, typical for strains of Caulobacter, were not found in members of this genus, while 15:0 was found only in trace amounts. The fatty acid 12:0 $3 \mathrm{OH}$, present in all Brevundimonas strains, was found in trace amounts only in Maricaulis strain MCS 26. All Maricaulis strains contained $11: 0$ iso $3 \mathrm{OH}, 17: 0$ iso, $17: 1$ iso $\omega 9 c$

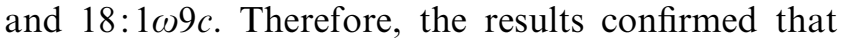
these fatty acids are useful biomarkers to distinguish between these three genera. Within the genus Maricaulis, strains MCS $25^{\mathrm{T}}$, VKM B-1513 $3^{\mathrm{T}}$, VKM B1514 and MCS 26 differ from all other Maricaulis strains by higher content of the fatty acids 18:0,11methyl 18:1 $15 t$ (ECL 18.080), ECL 18.424 and ECL 18.797 and the lack of $16: 1 \omega 9 c$. Maricaulis strains MCS $25^{\mathrm{T}}$ and MCS 26 have the lowest contents of 17 : 1 iso $\omega 9 c$ of all Maricaulis strains analysed so far. Maricaulis strains MCS $6^{\mathrm{T}}$ and MCS $18^{\mathrm{T}}$ have the highest content of $17: 1$ iso $\omega 9 c$ of all Maricaulis strains, but almost no $18: 0$ or $11: 0$ iso $3 \mathrm{OH}$. Finally, strains VKM B-1513 ${ }^{\mathrm{T}}$ and VKM B-1514 have large amounts of $11: 0$ iso $3 \mathrm{OH}$. Considering the fact that the 16S rRNA gene sequences of the Maricaulis species are very similar ( $>99 \%$ similarity), the fatty acids of the total lipids proved to be a powerful tool for the discrimination of the distinct Maricaulis species.

The tendency of caulobacteria to have large amounts of glycolipid was corroborated in this study, and a multitude of different glycolipids was identified. NMR and MS of the polar lipid fraction revealed that all glycolipids belong to the $\alpha$-glucosyl and $\alpha$ glucuronosyl diacyl glycerol types. The latter is the more abundant and diverse of the two. Surprisingly, phosphoglycerols are rare and found only in M. maris and the closely related strain MCS 28 . In Maricaulis strains, phospholipids are mainly replaced by sulfolipids, which are the main polar lipids in Maricaulis strain VKM B-1513 ${ }^{\mathrm{T}}$. In contrast to $M$. maris, phospholipids were not found in any of the novel Maricaulis species, and taurineamides were also absent. Instead of these lipids, sulfolipids based on glucose, like the glycolipids, and belonging to the SQDG type, were detected. The largest amounts and the greatest variety of these lipids were elucidated in Maricaulis strains VKM B-1513 ${ }^{\mathrm{T}}$ and VKM B-1514. This species is remarkable in this respect compared with all other Maricaulis species. A number of these sulfolipids are described here for the first time. This makes this species a much better producer of these compounds than various cyanobacteria, which have been used to produce such lipids possessing anti-HIV-
1 (Gustafson et al., 1989) and anti-tumour-promoter activities (Shirahashi et al., 1993).

\section{Conclusions}

Due to the heterogeneity of the isolates of Maricaulis, distinct taxa can be discerned and the proposal of four novel species of Maricaulis is justified.

\section{Description of Maricaulis parjimensis sp. nov.}

Maricaulis parjimensis (par.ji.men'sis. N.L. adj. parjimensis of Parjim, the capital of the Indian state of Goa, referring to the isolation of the type strain from the nearby coast).

Can grow on PYE medium with 5-100 $\mathrm{g} \mathrm{NaCl}^{-1}$, with optimal growth between 20 and $80 \mathrm{~g} \mathrm{NaCl}^{-1}$. No growth is observed without $\mathrm{NaCl}$; slow growth is also found with $100 \mathrm{~g} \mathrm{NaCl}^{-1}$. Optimal growth temperature is $30-40{ }^{\circ} \mathrm{C}$; does not grow at 10 or $50{ }^{\circ} \mathrm{C}$. Characterized by two major fatty acids, 18:0 and 18: $1 \omega 7$; minor fatty acids are 17:0, 17:1 $108 c$ and 18 : $1 \omega 9 c$. Polar lipids are $\alpha$-D-glucopyranosyl diacylglycerol, $\alpha$-D-glucuronopyranosyl diacylglycerol and SQDG, but no phosphatidyl diacylglycerol or $\alpha$-Dglucuronopyranosyl diacylglycerol taurineamide. Isolated from sea water off the coast of Goa, India. The $\mathrm{G}+\mathrm{C}$ content of the type strain is $63.0 \mathrm{~mol} \%$. The type strain is strain MCS $25^{\mathrm{T}}\left(=\mathrm{LMG} 19863^{\mathrm{T}}=\mathrm{CIP}\right.$ $\left.107440^{\mathrm{T}}\right)$.

\section{Description of Maricaulis salignorans sp. nov.}

Maricaulis salignorans (sa.lig.nor'ans. L. n. sal salt; L. adj. ignorans ignoring; N.L. adj. salignorans saltignoring, referring to the ability to grow without added salt).

The description is the same as that given for the genus (Abraham et al., 1999), with the following additional characteristics. Can grow on PYE medium with $0-80 \mathrm{~g}$ $\mathrm{NaCll}^{-1}$, with optimal growth between 20 and $60 \mathrm{~g}$ $\mathrm{NaCl}^{-1}$. Although $\mathrm{NaCl}$ is required for optimal growth, only slightly reduced growth is observed without $\mathrm{NaCl}$. This fairly rapid growth in freshwater is unusual for this genus and is distinct from M. maris (synonym $C$. halobacteroides) and Maricaulis strain MCS 26. Strains do not tolerate salt concentrations above $80 \mathrm{~g} \mathrm{NaCl}^{-1}$. Characterized by two major fatty acids, $16: 0$ and $17: 1$ iso $\omega 9 c$; minor fatty acids are 14 : $1 \omega 5,17: 1 \omega 8 c$, iso-17:0 and 17:0. Polar lipids are $\alpha$-Dglucopyranosyl diacylglycerol, $\alpha$-D-glucuronopyranosyl diacylglycerol and SQDG, but no phosphatidyl diacylglycerol or $\alpha$-D-glucuronopyranosyl diacylglycerol taurineamide. The $\mathrm{G}+\mathrm{C}$ content of the type strain is $63.3 \mathrm{~mol} \%$. Isolated from sea water off Salsbury Point County Park, WA, USA. The type strain is strain MCS $18^{\mathrm{T}}\left(=\mathrm{LMG} 19864^{\mathrm{T}}=\right.$ CIP $107439^{\mathrm{T}}$ ). 


\section{Description of Maricaulis washingtonensis sp. nov.}

Maricaulis washingtonensis (wa.shing.ton.en'sis. N.L. adj. washingtonensis of the US state of Washington, referring to the location of isolation of the type strain).

The description is the same as those given for the genus (Abraham et al., 1999) and for M. salignorans, with the following additional characteristics. Can grow on PYE medium with $0-80 \mathrm{~g} \mathrm{NaCl}^{-1}$, with optimal growth between 20 and $40 \mathrm{~g} \mathrm{NaCl}^{-1}$. Although $\mathrm{NaCl}$ is required for optimal growth, only slightly reduced growth is observed without $\mathrm{NaCl}$. At $\mathrm{NaCl}$ concentrations above $40 \mathrm{~g}^{-1}$, a long decline of the growth rate is observed until, for $100 \mathrm{~g} \mathrm{NaCl} \mathrm{l}^{-1}$, no growth is observed. The $\mathrm{G}+\mathrm{C}$ content of the type strain is $63.0 \mathrm{~mol} \%$. A DNA-DNA binding value of $59 \%$ was found between $M$. washingtonensis MCS $6^{\mathrm{T}}$ and $M$. salignorans MCS $18^{\mathrm{T}}$. Isolated from sea water from the Inner Marina, Edmonds, WA, USA. The type strain is strain MCS $6^{\mathrm{T}}\left(=\mathrm{LMG} 19865^{\mathrm{T}}=\right.$ CIP $\left.107441^{\mathrm{T}}\right)$.

\section{Description of Maricaulis virginensis sp. nov.}

Maricaulis virginensis (vir.gin.en'sis. N.L. adj. virginensis from the Virgin Islands).

The description is the same as that given for the genus (Abraham et al., 1999), with the following additional characteristics. All strains are characterized by two major fatty acids, 17:0 and 18:1 $1 \omega 7$; minor fatty acids are 14:0, 16:0, 17:0 iso and 18:0. The main polar lipids are $\alpha$-sulfoquinovosyl diacylglycerols. Cannot grow on PYE medium without $\mathrm{NaCl}$, and optimal growth occurs between 5 and $100 \mathrm{~g} \mathrm{NaCl} \mathrm{l}^{-1}$. Grows at temperatures between 10 and $40{ }^{\circ} \mathrm{C}$, with optimal growth at $20-40{ }^{\circ} \mathrm{C}$. A DNA-DNA binding value of $83 \%$ was found between $M$. virginensis strains VKM B-1513 ${ }^{\mathrm{T}}$ and VKM B-1514. A DNA-DNA binding value of $70 \%$ was found between $M$. virginensis VKM B-1513 ${ }^{\mathrm{T}}$ and strain MCS 26 (= LMG 19862). This is just at the margin to include this strain in this taxon; however, strain MCS 26 displays a number of differences from $M$. virginensis; therefore, it is not included here in this species. The type strain was obtained from deep sea water near a hydrothermal vent off the Virgin Islands. The $\mathrm{G}+\mathrm{C}$ content of the type strain is $65.2 \mathrm{~mol} \%$. The type strain is strain VKM $\quad$ B-1513 $3^{\mathrm{T}} \quad\left(=\mathrm{LMG} \quad 21018^{\mathrm{T}}=\mathrm{VC}-5^{\mathrm{T}}=\mathrm{CIP}\right.$ $\left.107438^{\mathrm{T}}\right)$. Strain VC-13 (=VKM B-1514) is a closely related strain.

\section{ACKNOWLEDGEMENTS}

We are indebted to Dagmar Wenderoth and Tanja Jeschke for skilful microbiological characterization of the strains, Annette Krüger for sequencing, Ruprecht Christ for measuring the mass spectra and Peter Wolff for chemical analysis. M.V. would like to thank Johan Goris for performing the determination of the DNA base compositions. This work was supported by grants of the German Federal Ministry for Science, Education and Research (project no. 0319433C) and the European Union within the
T-project 'High Resolution Automated Microbial Identification and Application to Biotechnologically Relevant Ecosystems'.

\section{REFERENCES}

Abraham, W.-R., Meyer, H., Lindholst, S., Vancanneyt, M. \& Smit, J. (1997). Phospho- and sulfolipids as biomarkers of Caulobacter, Brevundimonas and Hyphomonas. Syst Appl Microbiol 20, 522-539.

Abraham, W.-R., Strömpl, C., Meyer, H. \& 8 other authors (1999). Phylogeny and polyphasic taxonomy of Caulobacter species. Proposal of Maricaulis gen. nov. with Maricaulis maris (Poindexter) comb. nov. as the type species, and emended description of the genera Brevundimonas and Caulobacter. Int J Syst Bacteriol 49, 1053-1073.

Abraham, W.-R., Strömpl, C., Vancanneyt, M., Lünsdorf, H. \& Moore, E. R. B. (2001). Determination of the systematic position of the genus Asticcacaulis Poindexter by a polyphasic analysis. Int J Syst Evol Microbiol 51, 27-34.

Anast, N. \& Smit, J. (1988). Isolation and characterization of marine caulobacters and assessment of their potential for generic experimentation. Appl Environ Microbiol 54, 809-817.

Anzai, Y., Kim, H., Park, J.-Y., Wakabayashi, H. \& Oyaizu, H. (2000). Phylogenetic affiliation of the pseudomonads based on $16 \mathrm{~S}$ rRNA sequence. Int J Syst Evol Microbiol 50, 1563-1589.

Batrakov, S. G., Nikitin, D. I. \& Pitryuk, I. A. (1996). A novel glycolipid, 1,2-diacyl-3- $\alpha$-D-glucuronopyranosyl-sn-glycerol taurine amide, from the budding seawater bacterium Hyphomonas jannaschiana. Biochim Biophys Acta 1302, 167-176.

Bligh, E. G. \& Dyer, W. J. (1959). A rapid method for total lipid extraction and purification. Can J Biochem Physiol 37, 911-917.

Elomari, M., Coroler, L., Verhille, S., Izard, D. \& Leclerc, H. (1997). Pseudomonas monteilii sp. nov., isolated from clinical specimens. Int $J$ Syst Bacteriol 47, 846-852.

Ezaki, T., Hashimoto, Y. \& Yabuuchi, E. (1989). Fluorometric deoxyribonucleic acid-deoxyribonucleic acid hybridization in microdilution wells as an alternative to membrane filter hybridization in which radioisotopes are used to determine genetic relatedness among bacterial strains. Int J Syst Bacteriol 39, 224-229.

Felsenstein, J. (1989). PHYLIP - phylogeny inference package (version 3.2). Cladistics 5, 164-166.

Guasp, C., Moore, E. R. B., Lalucat, J. \& Bennasar, A. (2000). Utility of internally transcribed $16 \mathrm{~S}-23 \mathrm{~S}$ rDNA spacer regions for the definition of Pseudomonas stutzeri genomovars and other Pseudomonas species. Int J Syst Evol Microbiol 50, 1629-1639.

Gustafson, K. R., Cardellina, J. H., II, Fuller, R. W., Weislow, O. S., Kiser, R. F., Snader, K. M., Patterson, G. M. L. \& Boyd, M. R. (1989). AIDS-antiviral sulfolipids from cyanobacteria (blue-green algae). J Natl Cancer Inst 81, 1254-1258.

Gutell, R. R., Weiser, B., Woese, C. R. \& Noller, H. F. (1985). Comparative anatomy of 16S-like ribosomal RNA. Prog Nucleic Acid Res Mol Biol 32, 155-216.

Hauben, L., Vauterin, L., Swings, J. \& Moore, E. R. B. (1997). Comparison of $16 \mathrm{~S}$ ribosomal DNA sequences of all Xanthomonas species. Int J Syst Bacteriol 47, 328-335.

Henrici, A. T. \& Johnson, D. E. (1935). Studies on freshwater bacteria. II. Stalked bacteria, a new order of schizomycetes. J Bacteriol 30, 61-93.

Jannasch, H. W. \& Jones, G. E. (1960). Caulobacter in sea water. Limnol Oceanogr 5, 432-433.

Keswani, J. \& Whitman, W. B. (2001). Relationship of 16S rRNA sequence similarity to DNA hybridization in prokaryotes. Int $J$ Syst Evol Microbiol 51, 667-678.

Löffler, F. (1890). Weitere Untersuchungen über die Beizung und Färbung der Geisseln bei den Bakterien. Zentbl Bakteriol Parasitenkd 7, 625-639.

Maidak, B. L., Cole, J. R., Lilburn, T. G. \& 7 other authors (2001). The RDP-II (Ribosomal Database Project). Nucleic Acids Res 29, 173-174. 
Marmur, J. (1961). A procedure for the isolation of deoxyribonucleic acid from micro-organisms. J Mol Biol 3, 208-218.

Mesbah, M., Premachandran, U. \& Whitman, W. B. (1989). Precise measurement of the $\mathrm{G}+\mathrm{C}$ content of deoxyribonucleic acid by highperformance liquid chromatography. Int J Syst Bacteriol 39, 159-167.

Moore, E. R. B., Krüger, A. S., Hauben, L., Seal, S. E., Daniels, M. J., De Baere, R., De Wachter, R., Timmis, K. N. \& Swings, J. (1997). $16 \mathrm{~S}$ rRNA gene sequence analyses and inter- and intrageneric relationships of Xanthomonas species and Stenotrophomonas maltophilia. FEMS Microbiol Lett 151, 145-153.

Mullis, K. B. \& Faloona, F. A. (1987). Specific synthesis of DNA in vitro via a polymerase-catalyzed chain reaction. Methods Enzymol 155, 335-350.

Murphy, R. C. \& Harrison, K. A. (1994). Fast atom bombardment mass spectrometry of phospholipids. Mass Spectrom Rev 13, 57-75.

Neefs, J.-M., Van de Peer, Y., De Rijk, P., Goris, A. \& De Wachter, R. (1991). Compilation of small ribosomal subunit RNA sequences. Nucleic Acids Res 19 (Suppl.), 1987-2015.

Nishimori, E., Kita-Tsukamoto, K. \& Wakabayashi, H. (2000). Pseudomonas plecoglossicida sp. nov., the causative agent of bacterial haemorrhagic ascites of ayu, Plecoglossus altivelis. Int J Syst Evol Microbiol 50, 83-89.

Osterhout, G. J., Shull, V. H. \& Dick, J. D. (1991). Identification of clinical isolates of Gram-negative nonfermentative bacteria by an automated cellular fatty acid identification system. J Clin Microbiol 29, 1822-1830.

Poindexter, J. S. (1964). Biological properties and classification of the Caulobacter group. Bacteriol Rev 28, 231-295.

Poindexter, J. S. (1981a). Oligotrophy. Fast and famine existence. In Microbial Ecology, vol. 5, pp. 63-89. Edited by M. Alexander. New York: Plenum.

Poindexter, J. S. (1981b). The caulobacters: ubiquitous unusual bacteria. Microbiol Rev 45, 123-179.
Shirahashi, H., Murakami, N., Watanabe, M., Nagatsu, A., Sakakibara, J., Tokuda, H., Nishino, H. \& Iwashima, A. (1993). Isolation and identification of anti-tumor-promoting principles from the fresh-water cyanobacterium Phormidium tenue. Chem Pharm Bull 41, 1664-1666.

Stackebrandt, E. \& Goebel, B. M. (1994). Taxonomic note: a place for DNA-DNA reassociation and 16S rRNA sequence analysis in the present species definition in bacteriology. Int J Syst Bacteriol 44, 846-849.

Stahl, D. A., Key, R., Flesher, B. \& Smit, J. (1992). The phylogeny of marine and freshwater caulobacters reflects their habitat. $J$ Bacteriol 174, 2193-2198.

Staley, J. T. (1968). Prosthecomicrobium and Ancalomicrobium: new prosthecate freshwater bacteria. J Bacteriol 95, 1921-1942.

Staley, J. T., Konopka, A. E. \& Dalmasso, J. P. (1987). Spatial and temporal distribution of Caulobacter spp. in two mesotrophic lakes. FEMS Microbiol Ecol 45, 1-6.

Stoesser, G., Baker, W., van den Broek, A. \& 11 other authors (2001). The EMBL nucleotide sequence database. Nucleic Acids Res 29, 17-21.

Tamaoka, J. \& Komagata, K. (1984). Determination of DNA base composition by reversed-phase high-performance liquid chromatography. FEMS Microbiol Lett 25, 125-128.

Vancanneyt, M., Witt, S., Abraham, W.-R., Kersters, K. \& Fredrickson, H. L. (1996). Fatty acid content in whole-cell hydrolysates and phospholipid fractions of pseudomonads: a taxonomic evaluation. Syst Appl Microbiol 19, 528-540.

Wayne, L. G., Brenner, D. J., Colwell, R. R. \& 9 other authors (1987). Report of the ad hoc committee on reconciliation of approaches to bacterial systematics. Int J Syst Bacteriol 37, 463-464.

Wilson, K. (1987). Preparation of genomic DNA from bacteria. In Current Protocols in Molecular Biology, pp. 241-245. Edited by F. M. Ausubel, R. Brent, R. E. Kingston, D. D. Moore, J. G. Seidman, J. A. Smith \& K. Struhl. New York: Wiley. 